\title{
The effect of supplementation with polysaccharides, nucleotides, acidifiers and Bacillus strains in fish meal and soy bean based diets on growth performance in juvenile turbot (Scophthalmus maximus)
}

\author{
V.I. Fuchs ${ }^{\text {a }}$, J. Schmidt ${ }^{\text {b,d }}$, M.J. Slater ${ }^{\text {b,d }}$, J. Zentek ${ }^{c}$, B.H. Buck ${ }^{\text {d,e }}$, D. Steinhagen ${ }^{\text {a,* }}$ \\ a Fish Disease Research Unit, Centre of Infectious Diseases, University of Veterinary Medicine Hannover, Buenteweg 17, 30559 Hannover, Germany \\ b Institute for Marine Resources GmbH, Bussestraße 27, 27570 Bremerhaven, Germany \\ c Institute of Animal Nutrition, Department of Veterinary Medicine, Freie Universität Berlin, Königin-Luise-Str.49, 14195 Berlin, Germany \\ d Alfred Wegener Institute for Polar and Marine Research, Dep. Marine Aquaculture, Bussestraße 27, 27570 Bremerhaven, Germany \\ e University of Applied Sciences, Applied Marine Biology, An der Karlstadt 8, 27568 Bremerhaven, Germany
}

\section{A R T I C L E I N F O}

\section{Article history:}

Received 21 August 2014

Received in revised form 4 December 2014

Accepted 5 December 2014

Available online 12 December 2014

\section{Keywords:}

Turbot Scophthalmus maximus

Feed additive

Fish meal replacement

Plant protein

Growth performance

Feed utilization

\begin{abstract}
A B S T R A C T
The investigation and application of a wide range of dietary supplements, such as probiotics, prebiotic and other additives, are increasingly popular in aquaculture research and practice. To date few studies have attempted to quantify the value of commercially available additives in improving growth performance of juvenile turbot (Scophthalmus maximus) and in compensating potential growth reduction resulting from high levels of plant protein (PP) in carnivorous fish diets.

Two experiments were conducted to investigate the effect of different active ingredients in diet additives on turbot. I) Five diets supplemented with (1) yeast b-glucan and mannan oligosaccharides (GM), (2) alginic acid from brown algal extracts (AC), (3) yeast nucleotides and RNA (NR), (4) potassium diformate (PDF) and (5) bacteria strains Bacillus subtilis and B. licheniformis (BS), containing fish meal (FM) as the only protein source, were fed to turbots (initial weight $48.8 \mathrm{~g} \pm 5.2 \mathrm{~g}$ ) over 112 days. II) Four diets supplemented with (1) GM, (2) AC, (3) NR and (4) BS, containing soy protein concentrate (SPC) and wheat gluten (WG) as a partial replacement of FM, were fed to turbots (initial weight $95.8 \mathrm{~g} \pm 17.7 \mathrm{~g}$ ) over 84 days. A non-supplemented FM diet (exp. I) and an FM- and PP-based diet (exp. II), respectively, were used as control diets.

Diet additives did not promote additional weight gain, specific growth rate (SGR), daily feed intake (DFI) and feed conversion ratio (FCR) in turbot fed FM- or PP-based diets $(p>0.05)$ when compared to isocaloric control diets in both experiments. Growth of turbots fed the high FM content control diet (II) was significantly higher than all other treatments $(\mathrm{p}<0.01)$. Body proximate composition, condition factor $(\mathrm{K})$ and liver index $(\mathrm{HSI})$ remained unaffected by additive supplementation in fish fed either FM or PP diets $(\mathrm{p}>0.05)$.

Results indicate that reported benefits for specific diet additives cannot be assumed to function or applied across species boundaries and age classes. In addition, dietary additive application may not be economically valid for larger animals and/or animals not exposed to specific culture-related stressors. The benefits of popular additives to high value species such as S. maximus remains to be tested under specific immune or physical stress situations and at crucial larval and early juvenile stages.
\end{abstract}

c) 2014 Elsevier B.V. All rights reserved.

\section{Introduction}

Efforts to intensify aquaculture of valuable finfish, such as turbot (Scopthalmus maximus) can lead to increased stress, limited growth performance and poor welfare (Dalsgaard et al., 2013; Tal et al., 2009). Managing and avoiding outbreaks of infectious diseases are a challenge,

\footnotetext{
* Corresponding author. Tel.: + 49511 9538560; fax: + 49511953828560.

E-mail addresses: Vanessa.Hemsing@tiho-hannover.de (V.I. Fuchs), Jan.Schmidt@awi.de (J.Schmidt), Matthew.James.Slater@awi.de (M.J. Slater), Juergen.Zentek@fu-berlin.de (J.Zentek),Bela.H.Buck@awi.de (B.H. Buck), Dieter.Steinhagen@tiho-hannover.de (D. Steinhagen).
}

particularly, since EU regulations banned the use of antibiotics as growth and health promoters in livestock production (EU 2003; EC No 1831/2003). Animal health and nutritional conditions are of particular importance to fish farmers to ensure a high quality and sustainable product for the consumer. A proper diet is essential to improve fish health and reduce susceptibility of fish to diseases. Turbot diets are recommended to have 500 up to $650 \mathrm{~g} \mathrm{~kg}^{-1}$ protein (dry matter) with fish meal (FM) as the main protein source (Cho et al., 2005; Lee et al., 2003). For the growing production of turbot, $5.5 \mathrm{kt}$ to $12.7 \mathrm{kt}$ (2002 to 2012), in Europe, a rising demand for fish meal is evident (FAO, 2014).

However, rising demand and limited supply (due to the sustainable use of fish stocks and therefore reduced fishery production, El Niño 
events, etc.) of high quality fishmeal have increased prices and forced the feed industry to partly substitute FM with alternative protein sources, mainly protein-rich plant ingredients (Rana et al., 2009; Tacon and Metian, 2008; Watanabe, 2002). Soy protein concentrate (SPC) and wheat gluten are popular alternative protein sources in aquafeeds due to their favorable profile of essential amino acids (EAAs), competitive price and availability (Gatlin et al., 2007; Hardy, 2010; Storebakken et al., 2000). Substitution with plant protein (PP) can, however, reduce growth performance, feed utilization and fish health due to diminished palatability, EAA deficiency, reduced energy content, antinutritional factors and lower nutrient digestibility compared to fish meal (Bakke-McKellep and Refstie, 2008; Bonaldo et al., 2011; Francis et al., 2001; Krogdahl et al., 2010). An alternative approach to reduce adverse factors of PPs may be the inclusion of diet additives that can improve growth performance in fish and, possibly, compensate performance loss in low FM diets.

A range of diet additives, including probiotics, prebiotics, acidifiers and plant or animal derived extracts, are commercially available for aquatic animals. Previous studies have evaluated several of these additives on their effect on growth performance, immune response and disease resistance, as well as intestinal microbial communities for various fish species (Balcázar et al., 2006; Kesarcodi-Watson et al., 2008; Merrifield et al., 2010; Ringø et al., 2010). The polysaccharides beta-1,3/1,6glucans (BG) and mannan oligosaccharides (MOS), isolated from cell walls of yeasts, plants, algae, fungi or bacteria, are widely accepted as diet ingredients with positive effects on growth and health (Bohn and BeMiller, 1995; Meena et al., 2013; Zeković et al., 2005). Treatments with BG and MOS proved to promote growth performance in fish (Ai et al., 2007; Andrews et al., 2009; Kühlwein et al., 2014; Li et al., 2008; Misra et al., 2006; Staykov et al., 2007; Torrecillas et al., 2012; Yoo et al., 2007).

Among the many other substances and extracts investigated as diet additives, macroalgae and macroalgal extracts are rich in polysaccharides (e.g. alginic acid, laminarin, fucoidan) and contain bioactive substances (e.g. vitamins or polyphenols) that are known to affect animal health (Buchholz et al., 2012; Fleurence, 1999; Gupta and Abu-Ghannam, 2011; Holdt and Kraan, 2011; MacArtain et al., 2007). Macroalgae extracts containing alginic acids are reported to enhance growth performance in a variety of fish species (Ahmadifar et al., 2009; Heidarieh et al., 2011, 2012; Sheikhzadeh et al., 2012). Dietary uptake of exogenous nucleotides, isolated from yeast, may optimize cell proliferation in order to promote rapid growth, as the synthesis of nucleotides is a metabolically costly process (Sanderson and He, 1994). Particularly under stressful conditions additional nucleotides can be needed, for instance, for further signal transduction or immune cell proliferation (Carver and Walker, 1995; Li and Gatlin, 2006). The application of nucleotides has demonstrated a positive influence on growth performance when added to formulated fish diets (Burrells et al., 2001b; Lin et al., 2009; Tahmasebi-Kohyani et al., 2012).

Furthermore, acidifiers consisting of organic acids and their salts, used for instance as preservatives, are considered as promising growth promoters in animals (Lückstädt, 2008). Dietary supplementation of citric acid and potassium diformate showed improved growth and feed utilization in some fish species (Abu Elala and Ragaa, 2014; Baruah et al., 2007; Hossain et al., 2007). In addition, probiotics or beneficial bacteria are known to control pathogens through a variety of mechanisms and affect intestinal microbial communities (KesarcodiWatson et al., 2008). In some fish species the dietary inclusion of Bacillus subtilis and $B$. licheniformis strains had a positive effect on growth performance (Bairagi et al., 2004; He et al., 2011; Kumar et al., 2006; Raida et al., 2003).

Despite the progress made with various fish species, the effect of the above-mentioned feed additives on growth performance and feed utilization of commercially important turbot remains limited (Li et al., 2008; Peng et al., 2013; Yun et al., 2011). Few studies have investigated the effectiveness of diet additives on performance and health in fish comparing FM- and PP-based diets (Dimitroglou et al., 2010; Peng et al., 2013; Salze et al., 2010; Yun et al., 2011). Applied research, such as the current study, is needed to fill the knowledge gaps regarding feed additives' potential to support the increased use of plant proteins in diets for carnivorous fish species. The current study aims to determine the effect of selected feed additives on growth performance of turbot fed FM- and PP-based diets.

\section{Materials and methods}

Two trials were carried out to test the capacity of commercially available feed additives with the active ingredients, (1) yeast b-glucan and mannan oligosaccharides (GM), (2) alginic acid from brown algal extracts (AC), (3) purified yeast nucleotides and ribosomal RNA (NR), (4) acidifier potassium diformate (PDF; only used in trial I) and (5) probiotic bacteria strains Bacillus subtilis and B. licheniformis (BS), to improve growth performance (I) and/or to compensate performance loss in juvenile turbots (S. maximus) resulting from dietary fish meal reduction (II). The growth performance and feed utilization of fish fed (I) a high quality diet with $77 \%$ fish meal content and (II) a fish meal reduced diet with $32 \%$ fish meal were determined. Feeding experiments were conducted in two separate trials I (January to May 2013) and II (October 13 to January 14) as the experimental set-up and high number of treatments did not allow a simultaneous performance of both trials in one experiment.

\subsection{Trial I: Experimental setup}

Juvenile turbot, approx. $15 \mathrm{~g}$ in weight, were obtained from Maximus A/S (Bedsted Thy, Denmark). Fish were examined for infectious diseases at the beginning and at the end of the experiments to confirm suitability as experimental animals. Prior to the experiment, fish were acclimatized for 10 weeks in a recirculating aquaculture system (RAS) in the Center for Aquaculture Research (ZAF) at the Institute for Marine Resources (IMARE) in Bremerhaven (Germany). During acclimatization turbot were fed in the morning and the afternoon at a rate of $2.0 \% \mathrm{BW}^{-1} \mathrm{day}^{-1}$ of a commercial dry feed with $55 \%$ crude protein and 16\% crude fat (R Europa 15, 2 mm diameter; Skretting ARC, Stavanger, Norway). The system had a total water volume of $40 \mathrm{~m}^{3}$ and was equipped with drum filter, protein skimmer, moving bed biofilter and disinfection unit (Ozon generator; Sander Aquatec $\mathrm{GmbH}$, Uetze-Eltze, Germany). The experiments were performed under the guidelines of the local authority (Department of Food Safety, Veterinary Affairs and Plant Protection) in Bremen with the permission to carry out animal experiments (522-27-11/02-00(112)).

The photoperiod was maintained at a $12 \mathrm{~h}$ light: $12 \mathrm{~h}$ dark cycle throughout. Water parameters, such as dissolved oxygen $(8.8 \pm$ $\left.0.3 \mathrm{mg} \mathrm{^{-1 }}\right)$, temperature $\left(16.7 \pm 0.5{ }^{\circ} \mathrm{C}\right)$ and salinity $(30.8 \pm$ $3.3 \mathrm{~g} \mathrm{l}^{-1}$ ) were monitored constantly with a SC 1000 Multiparameter Universal Controller (Hach Lange GmbH, Düsseldorf, Germany). Ammonia, nitrite and nitrate were measured daily before feeding $(0.05 \pm$ $0.09 \mathrm{mg} \mathrm{l}^{-1} \mathrm{NH}_{4}-\mathrm{N}, 0.33 \pm 0.18 \mathrm{mg} \mathrm{l}^{-1} \mathrm{NO}_{2}-\mathrm{N}, 390.9 \pm 92.1 \mathrm{mg} \mathrm{l}^{-1}$ $\mathrm{NO}_{3}-\mathrm{N}$; photometer DR 2800; Hach Lange $\mathrm{GmbH}$, Düsseldorf, Germany).

A total of 1,440 turbot with an initial mean body weight of $48.8 \mathrm{~g}$ $( \pm 5.2 \mathrm{~g})$ and initial mean standard length of $13.7 \mathrm{~cm}( \pm 0.6 \mathrm{~cm})$ were randomly allocated to 36 experimental tanks $\left(0.8 \mathrm{~m}^{2}\right.$ bottom surface, $500 \mathrm{~L}$ water volume; 40 individuals $\operatorname{tank}^{-1}$; stocking density 50 fish $\mathrm{m}^{-2}$ or $2.4 \mathrm{~kg} \mathrm{~m}^{-2}$ ). Six feeding groups were assigned to the tanks allowing six replicates per treatment. Over the entire experimental period of 16 weeks fish were hand-fed with floating pellets to apparent satiation twice a day (10:00 and 14:00). All uneaten feed was netted ( mash size $=500 \mu \mathrm{m}$ ) out of the tanks 30 min after start of the feeding, dried at $50{ }^{\circ} \mathrm{C}$ for $24 \mathrm{~h}$ and weighed. The weights of daily recovered pellets were corrected for soluble losses using a factor which was calculated from the difference between dry weight of pellets before and after 
recovering. Therefore, pellets (approximately $5 \mathrm{~g}$ ) of each diet were soaked in system water for $15 \mathrm{~min}$, dried at $50{ }^{\circ} \mathrm{C}$ for $24 \mathrm{~h}$ and weighed.

\subsection{Trial I: Experimental diets}

A control diet (CT) was formulated with $77 \%$ FM to contain $61 \%$ crude protein and $22 \mathrm{MJ} \mathrm{kg}^{-1}$ gross energy. The composition and concentration of nutrients (moisture, crude protein, crude fat, ash, phosphorus and calcium) and gross energy of the six formulated diets are presented in Table 1. The other six experimental diets were formulated with regards to an isonitrogenous and isocaloric content and were supplemented with active ingredients of commercially available feed additives: (1) a yeast (Saccharomyces cerevisiae) product consisting of $20 \%$ beta-1,3/1,6 glucans and 17\% mannan oligosaccharides (ProEnMune, ProEn Protein and Energie GmbH, Soltau, Germany) (GM), (2) an alginic acid product of brown algal extracts containing 99\% Laminaria digitata and $1 \%$ Ascophyllum nodosum (Ergosan ${ }^{\circledR}$, Intervet/Schering-Plough Aquaculture, Saffron Walden, UK) (AC), (3) a product of purified yeast nucleotides (Cytidine-5 V-monophosphate (CMP), disodium uridine-5 $\mathrm{V}$-mono-phosphate (UMP), adenosine-5 V-monophosphate (AMP), disodium inosine-5 $\mathrm{V}$-monophosphate (IMP), disodium guanidine5 V-monophosphate (GMP)) and ribosomal RNA (Vannagen ${ }^{\circledR}$, Chemoforma Ltd., Augst, Switzerland) (NR), (4) an acidifier product of potassium diformate containing 35\% free formic acid, 35\% formate and $30 \%$ potassium (Aquaform ${ }^{\circledR}$, ADDCON/Nordic AS, Porsgrunn, Norway) (PDF) and (5) a probiotic product of bacteria strains Bacillus subtilis and B. licheniformis (Probiotic-plus.ru, Russia) (BS). The ingredients were mixed using a spiral mixer (WP Kemper President 75 AF-V, Emil Kemper GmbH, Rietberg, Germany) and extruded to floating pellets of $3 \mathrm{~mm}$ in diameter using a twin-screw extruder (Bühler 2-WellenExtruder DNDL-44, Bühler AG, Uzwil, Schweiz) at temperature of 95-

Table 1

Ingredients, nutrient composition in $\mathrm{g} \mathrm{kg}^{-1}$ dry matter (DM) and gross energy in $\mathrm{MJ} \mathrm{kg}^{-1}$ $\mathrm{DM}$ of the experimental diets in trial 1 .

\begin{tabular}{|c|c|c|c|c|c|c|}
\hline & \multicolumn{6}{|l|}{ Diets } \\
\hline & $\mathrm{CT}$ & GM & $\mathrm{AC}$ & NR & PDF & BS \\
\hline \multicolumn{7}{|l|}{ Ingredients $\left[\mathrm{g} \mathrm{kg}^{-1}\right]$} \\
\hline Fish meal $^{\mathrm{a}}$ & 777.0 & 777.0 & 777.0 & 777.0 & 777.0 & 777.0 \\
\hline Wheat gluten ${ }^{\mathrm{b}}$ & 30.0 & 29.5 & 29.5 & 28.0 & 30.0 & 30.0 \\
\hline Wheat starch ${ }^{\mathrm{b}}$ & 110.0 & 104.5 & 105.5 & 110.0 & 107.0 & 109.4 \\
\hline GM & 0.0 & 6.0 & 0.0 & 0.0 & 0.0 & 0.0 \\
\hline$A C$ & 0.0 & 0.0 & 5.0 & 0.0 & 0.0 & 0.0 \\
\hline NR & 0.0 & 0.0 & 0.0 & 2.0 & 0.0 & 0.0 \\
\hline PDF & 0.0 & 0.0 & 0.0 & 0.0 & 3.0 & 0.0 \\
\hline BS & 0.0 & 0.0 & 0.0 & 0.0 & 0.0 & 0.6 \\
\hline Fish oil $^{\mathrm{C}}$ & 74.0 & 74.0 & 74.0 & 74.0 & 74.0 & 74.0 \\
\hline Vitamin/mineral mixture ${ }^{\mathrm{d}}$ & 7.0 & 7.0 & 7.0 & 7.0 & 7.0 & 7.0 \\
\hline Titanium dioxide $\mathrm{e}^{\mathrm{e}}$ & 2.0 & 2.0 & 2.0 & 2.0 & 2.0 & 2.0 \\
\hline \multicolumn{7}{|l|}{ Nutrient composition ${ }^{\mathrm{f}}\left[\mathrm{g} \mathrm{kg}^{-1}\right]$} \\
\hline Moisture & 34 & 29 & 34 & 34 & 33 & 35 \\
\hline Crude protein & 614 & 621 & 611 & 617 & 618 & 604 \\
\hline Crude fat & 149 & 147 & 146 & 148 & 152 & 149 \\
\hline Crude ash & 136 & 134 & 137 & 134 & 139 & 138 \\
\hline Calcium & 30 & 29 & 29 & 29 & 29 & 31 \\
\hline Phosphorus & 21 & 21 & 21 & 21 & 21 & 22 \\
\hline Gross energy $\left[\mathrm{MJ} \mathrm{kg}^{-1}\right]^{\mathrm{g}}$ & 22 & 22 & 22 & 22 & 22 & 22 \\
\hline
\end{tabular}

$\mathrm{CT}=$ control, $\mathrm{GM}=$ b-glucan/MOS, $\mathrm{AC}=$ alginic acid, $\mathrm{NR}=$ nucleotides $/ \mathrm{RNA}, \mathrm{PDF}=$ potassium diformate and BS = Bacillus spp. Additive concentrations were recommended by manufacturers and literature (Burrells et al., 2001a,b; Lückstädt, 2008; Merrifield et al., 2011).

Köster Marine Proteins GmbH, Hamburg, Germany.

b Kröner Stärke, Ibbenbüren, Germany.

c Vereinigte Fischmehlwerke Cuxhaven GmbH \& Co KG, Cuxhaven, Germany.

d Spezialfutter Neuruppin GmbH \& Co. KG, Neuruppin, Germany.

e Kronos Titan GmbH \& Co.OHG, Nordenham, Germany.

${ }^{\mathrm{f}}$ Weender analysis (Dumas): moisture (VDLUFA Bd. III 3.1), crude protein (VDLUFA Bd. III 4.1.2), crude fat (VDLUFA Bd. III 5.1.1), ash (VDLUFA Bd. III 8.1); ICP-mass spectrometry: calcium and phosphor (PM DE01_018).

g Bomb calorimeter (6100, Parr Instrument GmbH, Frankfurt a. M., Germany). $110^{\circ} \mathrm{C}$. Subsequently, pellets were dried (Bühler OTW-25/50, Schweiz) and coated with oil under constant mixing using a wendel mixer (WV 240a, DIOSNA Dierks \& Söhne GmbH, Osnabrück, Germany). All diets were sieved at the end to discard fractions below $3 \mathrm{~mm}$.

\subsection{Trial II: Experimental setup}

The experimental set-up was identical to trial 1 (see Section 2.1). Water parameters, such as dissolved oxygen $\left(9.3 \pm 0.5 \mathrm{mg} \mathrm{l}^{-1}\right)$, temperature $\left(17.3 \pm 0.5^{\circ} \mathrm{C}\right)$ and salinity $\left(28.6 \pm 1.4 \mathrm{~g} \mathrm{l}^{-1}\right)$ were monitored constantly. Ammonia, nitrite and nitrate were measured in a three days interval before feeding $\left(0.01 \pm 0.02 \mathrm{mg} \mathrm{l}^{-1} \mathrm{NH}_{4}-\mathrm{N}, 0.04 \pm 0.03 \mathrm{mg} \mathrm{l}^{-1}\right.$ $\mathrm{NO}_{2}-\mathrm{N}, 80.6 \pm 16.7 \mathrm{mg} \mathrm{l}^{-1} \mathrm{NO}_{3}-\mathrm{N}$; photometer DR 2800).

900 turbot individuals with an initial mean body weight of $95.8 \mathrm{~g}$ $( \pm 17.7 \mathrm{~g})$ and initial mean standard length of $18.0 \mathrm{~cm}( \pm 1.1 \mathrm{~cm})$ were used for this experiment and randomly placed into the experimental tanks (25 individuals tank ${ }^{-1}$; stocking density 31.3 fish $\mathrm{m}^{-2}$ or $3.0 \mathrm{~kg} \mathrm{~m}^{-2}$ ). Each of the six feeding groups contained six replicates ( $\mathrm{n}=36$ tanks). Feeding was done as described for trail 1 (see 2.1) over a period of 12 weeks.

\subsection{Trial II: Experimental diets}

A high FM control diet with 58\% FM (C-HF) and a low FM control diet with $32 \%$ FM (C-LF) were formulated to contain $56 \%$ crude protein and $22 \mathrm{MJ} \mathrm{kg}^{-1}$ gross energy (Table 2). Protein content in C-LF was partly replaced with soy bean concentrate and wheat gluten with an inclusion of $56 \%$ PP. The reduction of FM to $32 \%$ was chosen as studies showed that growth performance in turbot was significantly decreased with a FM

Table 2

Ingredients, nutrient composition in $\mathrm{g} \mathrm{kg}^{-1}$ dry matter (DM) and gross energy in $\mathrm{MJ} \mathrm{kg}^{-1}$ DM of the experimental diets in trial 2.

\begin{tabular}{|c|c|c|c|c|c|c|}
\hline & \multicolumn{6}{|l|}{ Diets } \\
\hline & $\mathrm{C}-\mathrm{HF}$ & C-LF & GM & $\mathrm{AC}$ & NR & BS \\
\hline \multicolumn{7}{|l|}{ Ingredients [ $\mathrm{g} \mathrm{kg}^{-1}$ ] } \\
\hline Fish meal $^{\mathrm{a}}$ & 585.0 & 320.0 & 320.0 & 320.0 & 320.0 & 320.0 \\
\hline Soy protein concentrates ${ }^{a}$ & 125.0 & 250.0 & 250.0 & 250.0 & 250.0 & 250.0 \\
\hline Corn gluten ${ }^{\mathrm{b}}$ & 30.0 & 40.0 & 40.0 & 40.0 & 40.0 & 40.0 \\
\hline Wheat gluten ${ }^{c}$ & 20.0 & 147.0 & 146.7 & 146.8 & 146.9 & 147.0 \\
\hline Wheat starch ${ }^{c}$ & 184.0 & 160.0 & 154.3 & 155.2 & 158.1 & 159.4 \\
\hline GM & 0.0 & 0.0 & 6.0 & 0.0 & 0.0 & 0.0 \\
\hline$A C$ & 0.0 & 0.0 & 0.0 & 5.0 & 0.0 & 0.0 \\
\hline NR & 0.0 & 0.0 & 0.0 & 0.0 & 2.0 & 0.0 \\
\hline BS & 0.0 & 0.0 & 0.0 & 0.0 & 0.0 & 0.6 \\
\hline Fish oil $^{\mathrm{d}}$ & 45.0 & 72.0 & 72.0 & 72.0 & 72.0 & 72.0 \\
\hline Vitamin/mineral mixture $\mathrm{e}^{\mathrm{e}}$ & 10.0 & 10.0 & 10.0 & 10.0 & 10.0 & 10.0 \\
\hline Titanium dioxide $\mathrm{f}^{\mathrm{f}}$ & 1.0 & 1.0 & 1.0 & 1.0 & 1.0 & 1.0 \\
\hline \multicolumn{7}{|c|}{ Nutrient composition ${ }^{\mathrm{g}}\left[\mathrm{g} \mathrm{kg}^{-1}\right]$} \\
\hline Moisture & 72 & 70 & 66 & 65 & 74 & 64 \\
\hline Crude protein & 553 & 567 & 571 & 569 & 562 & 571 \\
\hline Crude fat & 117 & 112 & 112 & 112 & 118 & 113 \\
\hline Crude ash & 108 & 76 & 75 & 77 & 71 & 77 \\
\hline Calcium & 18 & 11 & 11 & 11 & 11 & 11 \\
\hline Phosphorus & 15 & 10 & 10 & 10 & 10 & 10 \\
\hline Gross energy $\left[\mathrm{MJ} \mathrm{kg}{ }^{-1}\right]^{\mathrm{h}}$ & 21 & 22 & 22 & 21 & 22 & 22 \\
\hline
\end{tabular}

$\mathrm{C}-\mathrm{HF}=$ high fish meal control, $\mathrm{C}-\mathrm{LF}=$ low fish meal control, $\mathrm{GM}=$ b-glucan/MOS, $\mathrm{AC}=$ alginic acid, NR = nucleotides/RNA and BS = Bacillus spp. Additive concentrations were recommended by manufacturers and literature (Burrells et al., 2001a,b; Merrifield et al., 2011).

a Köster Marine Proteins GmbH, Hamburg, Germany.

b Cargill Deutschland GmbH, Krefeld, Germany.

c Kröner Stärke, Ibbenbüren, Germany.

d Vereinigte Fischmehlwerke Cuxhaven GmbH \& Co KG, Cuxhaven, Germany.

e Spezialfutter Neuruppin GmbH \& Co. KG, Neuruppin, Germany.

${ }^{f}$ Kronos Titan GmbH \& Co.OHG, Nordenham, Germany.

g Weender analysis (Dumas): moisture (VDLUFA Bd. III 3.1), crude protein (VDLUFA Bd. III 4.1.2), crude fat (VDLUFA Bd. III 5.1.1), ash (VDLUFA Bd. III 8.1); ICP-mass spectrometry: calcium and phosphor (PM DE01_018).

h Bomb calorimeter (6100, Parr Instrument GmbH, Frankfurt a. M., Germany). 
content below $40 \%$ and a PP level above 30\%, respectively (Bonaldo et al., 2011; Day and Plascencia González, 2000). The other four experimental diets were formulated on the basis of control diet C-LF and were supplemented with commercially available feed additives: (1) GM, (2) AC, (3) NR and (4) BS (for details see 2.2). All diets were formulated with regards to an isonitrogenous and isocaloric content. Composition and concentration of crude nutrients, minerals and gross energy of the six formulated diets are presented in Table 2 . The preparation of the diets was identical to trial 1 (see 2.2). Diets were extruded to floating pellets of $5 \mathrm{~mm}$ in diameter.

\subsection{Sampling, measurements and calculations}

All fish were individually weighed and the total length was measured at the beginning and the end of the experiment as well as at 4-week intervals. Prior to weighing fish were starved for $24 \mathrm{~h}$. Deriving from weight and length measurements weight gain, specific growth rate (SGR) and body condition factor (K) were determined for each fish according to the formulae:

(1) Weight gain (g) = final weight - initial weight,

(2) SGR (\% body weight day $\left.{ }^{-1}\right)=[\ln$ (final weight) $-\ln$ (initial weight)]/feeding days $\times 100$,

(3) $\mathrm{K}(\%)=100 \times$ final body weight $\times$ final body length ${ }^{-3}$.

The actual total feed intake ( $\left.\mathrm{FI}_{\text {total }}\right)$ was determined by subtracting the dried feed remnants $\left(F_{\text {uneaten }}\right)$ from feed offered $\left(F_{\text {offered }}\right)$ after correcting for soluble losses during feeding:

(4) $\mathrm{FI}_{\text {total }}(\mathrm{g})=\mathrm{F}_{\text {offered }}-\left(\mathrm{F}_{\text {uneaten }} \times\right.$ factor $\left._{\text {soluble loss }}\right)$.

Daily feed intake (DFI) and feed conversion ratio (FCR) were calculated according to the formulae:

(5) DFI $\left(\% \mathrm{BW} \mathrm{day}^{-1}\right)=100 \times \mathrm{FI}_{\text {total }} /[$ (initial weight + final weight)/2]/feeding days,

(6) $\mathrm{FCR}=\mathrm{FI}_{\text {total }} /$ weight gain.

For a determination of the hepatosomatic index (HSI) in trial I, livers of 72 individuals (two fish per tank = 12 fish per treatment) were sampled after 16 weeks and, in trial II, livers of 108 individuals (three fish per tank $=18$ fish per treatment) were sampled after 12 weeks of feeding. Before sampling, fish were killed with an overdose $\left(500 \mathrm{mg} / \mathrm{L}^{-1}\right)$ of the anesthetic tricaine methane sulfonate (MS 222; Sigma-Aldrich Co. LLC., Munich, Germany). Liver weight and fish weight were recorded and the HSI was calculated for each fish according to the formula:

(7) HSI $(\%)=($ liver weight/final body weight $) \times 100$.

\subsection{Whole body composition}

At experimental outset 10 fish and at the end of the experiment six fish per dietary treatment $(n=6)$, respectively, were freeze-dried (Alpha 1-4 LSC, Martin Christ GmbH, Osterode a. H., Germany) and homogenized (grinder GRINDOMIX GM 200, Retsch GmbH, Haan, Germany) for an analysis for their respective proximate composition. The gross energy was determined using a bomb calorimeter (6100, Parr Instrument GmbH, Frankfurt a. M., Germany). Analysis for moisture, crude lipid (CL) and ash were carried out by Intertek Food Services GmbH (Bremen, Germany) following the VDLUFA protocols (Bd. III 3.1, Bd. III 5.1.1 and Bd. III 8.1). Total nitrogen content was determined by the Kjeldahl method (L 06.00-7 (mod.)). CP content of the fish body was calculated by multiplying $\mathrm{N}$ by 6.25 .

\subsection{Statistics}

Data are presented as mean \pm standard deviation (S.D.) for each treatment. The Sigma plot 11 for Windows (Systat Software Inc., San Jose, CA, USA) software package was used for statistical evaluations. Data of growth parameters, feed utilization, whole body composition and condition parameters (K, HSI) were tested for normality distribution by Shapiro-Wilk test. If normality or homogeneity of variances was confirmed, multiple comparisons were done by one-way analysis of variance (ANOVA) followed by the post hoc Tukey's Honestly Significant Difference (HSD) test or Dunn test. The non-parametric KruskalWallis test was used when the normality assumption was not met. Differences between set of comparisons were considered significant at a probability of error at $\mathrm{p}<0.05$.

\section{Results}

\subsection{Trial I}

\subsubsection{Mortalities, growth performance and body composition}

Mortality was low ( 0.4 to $2.2 \%, \mathrm{p}>0.05$; Table 3 ) and turbot remained otherwise healthy throughout the experiment. Mean initial weight (by treatment) ranged from $48.6 \pm 0.6 \mathrm{~g}$ to $49.0 \pm 0.3 \mathrm{~g}$. Final fish weight (g) and weight gain (g) ranged from $231.8 \pm 50.2$ (PDF) to $251.5 \pm 52.1(\mathrm{GM})$ and $183.2 \pm 12.1(\mathrm{PDF})$ to $202.9 \pm 12.2(\mathrm{GM})$, respectively (Table 3 ). SGR (\%) of fish ranged from $1.39 \pm 0.04$ (PDF) to $1.47 \pm 0.04(\mathrm{GM})$. No significant differences in growth performance were detected between dietary treatments $(p>0.05)$. Fish $\mathrm{DFI}\left(\% \mathrm{BW} \mathrm{d}^{-1}\right.$ ) ranged from $0.86 \pm 0.02$ (PDF) to $0.90 \pm 0.03$ (BS) across all treatments (Table 3 ). FCR of fish ranged from $0.73 \pm 0.01$ (CT) to $0.76 \pm 0.02$ (BS). Results of DFI and FCR showed no significant differences among all dietary treatments $(\mathrm{p}>0.05)$. Fish $\mathrm{K}(\%)$ ranged from $2.16 \pm 0.10(\mathrm{AC})$ to $2.21 \pm 0.04(\mathrm{CT})$ and fish HSI (\%) ranged from $1.07 \pm 0.13(\mathrm{AC})$ to $1.32 \pm 0.14(\mathrm{GM})$ across all treatments (Table 3 ). K and HSI did not significantly differ between dietary treatments $(\mathrm{p}>0.05)$.

Crude protein (\% dry matter (DM)) of the whole body composition ranged from $69.7 \pm 1.1$ (BS) to $72.3 \pm 2.0$ (PDF) (Table 4). Crude lipid (\% DM) ranged from $11.2 \pm 4.4(\mathrm{CT})$ to $13.7 \pm 0.8(\mathrm{BS})$ (Table 4 ). Gross energy (MJ kg-1 DM) ranged from $20.0 \pm 1.4$ (CT) to $21.5 \pm$ 0.8 (BS) (Table 4). All results were not significantly different among dietary treatments $(\mathrm{p}>0.05)$.

\subsection{Trial II}

\subsubsection{Mortalities, growth performance and body composition}

Turbot were healthy throughout the experiment and mortality rates were low (maximum $0.7 \%, \mathrm{p}>0.05$; Table 5 ). Weight (g) at experimental outset ranged between $95.7 \pm 0.1$ and $95.9 \pm 0.8$. Highest final weight $(299.5 \pm 92.0 \mathrm{~g})$, weight gain $(203.7 \pm 21.8 \mathrm{~g})$ and SGR $(1.35 \pm 0.09 \%)$ were observed in fish fed the high FM-diet (C-HF) (Table 5). Growth performance of fish was significantly different compared to fish fed the low FM-diets $(\mathrm{p}<0.01)$. Final weight, weight gain and SGR of fish fed the low FM-diets ranged from $246.3 \pm 71.1$ (NR) to $257.5 \pm 70.4(\mathrm{AC}), 150.3 \pm 15.3(\mathrm{NR})$ to $161.4 \pm 16.7$ (AC) and $1.12 \pm 0.08$ (NR) to $1.17 \pm 0.08(\mathrm{AC})$, respectively (Table 5). No significant differences were achieved between the low FM treatments $(\mathrm{p}>0.05)$. DFIs $\left(\% \mathrm{BW} \mathrm{d}^{-1}\right)$ ranged from $0.85 \pm 0.08(\mathrm{AC})$ to $0.95 \pm$ 0.05 (C-HF) (Table 5). The differences between fish DFIs of all treatments were not significant $(\mathrm{p}>0.05)$. FCRs of all dietary treatments ranged from $0.83 \pm 0.08$ (GM) to $0.78 \pm 0.01$ (C-HF) (Table 5). No significant differences were found among all treatments ( $\mathrm{p}>0.05)$. Fish $\mathrm{K}$ (\%) ranged from $1.97 \pm 0.08$ (BS) to $2.07 \pm 0.04$ (C-HF) and fish HSI (\%) ranged from $1.19 \pm 0.14$ (C-HF) to $1.40 \pm 0.19$ (BS) across all treatments (Table 5). K and HSI showed no significant differences between all dietary treatments $(\mathrm{p}>0.05)$. 
Table 3

Growth performance and feed utilization of turbot fed experimental diets for 112 days in trial 1.

\begin{tabular}{|c|c|c|c|c|c|c|}
\hline & $\mathrm{CT}$ & GM & $\mathrm{AC}$ & NR & PDF & BS \\
\hline Initial weight, $\mathrm{g}$ & $49.0 \pm 0.3$ & $48.6 \pm 0.6$ & $48.9 \pm 0.5$ & $49.0 \pm 0.2$ & $48.6 \pm 0.6$ & $48.8 \pm 0.2$ \\
\hline Final weight, g & $251.4 \pm 53.7$ & $251.5 \pm 52.1$ & $240.7 \pm 63.9$ & $242.3 \pm 53.9$ & $231.8 \pm 50.2$ & $249.2 \pm 60.3$ \\
\hline Weight gain, g & $202.4 \pm 20.9$ & $202.9 \pm 12.2$ & $191.5 \pm 29.4$ & $193.4 \pm 19.2$ & $183.2 \pm 12.1$ & $200.5 \pm 27.6$ \\
\hline SGR, \% day ${ }^{-1}$ & $1.46 \pm 0.07$ & $1.47 \pm 0.04$ & $1.42 \pm 0.11$ & $1.42 \pm 0.08$ & $1.39 \pm 0.04$ & $1.45 \pm 0.10$ \\
\hline DFI, \% day ${ }^{-1}$ & $0.88 \pm 0.03$ & $0.89 \pm 0.01$ & $0.88 \pm 0.03$ & $0.88 \pm 0.02$ & $0.86 \pm 0.02$ & $0.90 \pm 0.03$ \\
\hline FCR & $0.73 \pm 0.01$ & $0.74 \pm 0.01$ & $0.75 \pm 0.03$ & $0.74 \pm 0.02$ & $0.74 \pm 0.01$ & $0.76 \pm 0.02$ \\
\hline Mortality, \% & 0.0 & 0.0 & 2.2 & 0.4 & 0.9 & 0.9 \\
\hline $\mathrm{K}, \%$ & $2.21 \pm 0.04$ & $2.18 \pm 0.02$ & $2.16 \pm 0.10$ & $2.18 \pm 0.07$ & $2.17 \pm 0.07$ & $2.20 \pm 0.07$ \\
\hline HSI, \% & $1.25 \pm 0.22$ & $1.32 \pm 0.14$ & $1.07 \pm 0.13$ & $1.15 \pm 0.14$ & $1.11 \pm 0.24$ & $1.14 \pm 0.21$ \\
\hline
\end{tabular}

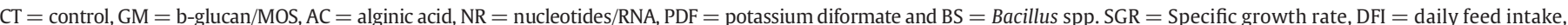
$\mathrm{FCR}=$ feed conversion ratio, $\mathrm{K}=$ condition factor, $\mathrm{HSI}=$ hepatosomatic index. Each value is mean \pm S.D. $(\mathrm{n}=6)$. No significant differences were identified $(\mathrm{p}>0.05$ ).

Crude protein (\% DM) of the whole body composition ranged from $67.2 \pm 5.1$ (NR) to $72.5 \pm 0.4$ (BS) (Table 6). Crude lipid (\% DM) ranged from $12.0 \pm 2.6(\mathrm{C}-\mathrm{HF})$ and $12.0 \pm 4.8(\mathrm{AC})$ to $15.6 \pm 2.3$ (NR). Gross energy (MJ $\left.\mathrm{kg}^{-1} \mathrm{DM}\right)$ ranged from $20.8 \pm 1.1(\mathrm{C}-\mathrm{LF})$ to $21.8 \pm 0.9$ (BS) (Table 6 ). All results were not significantly different among dietary treatments $(\mathrm{p}>0.05)$.

\section{Discussion}

Diet additives, classified as functional feeds, have recently attracted extensive attention and investment within the aquaculture industry. However, the cost of most additives and the challenge of incorporating them into extruded feeds have to be considered by evaluating benefits against investment. This study has for the first time shown that growth and feed utilization is not positively influenced by either of the five types of diet additives in growing turbot from $50 \mathrm{~g}$ weight up to $300 \mathrm{~g}$ in a recirculating system. Additive inclusion in extruded diets failed to improve performances of turbots fed either FM-based diets or diets containing partial FM replacement by soy and wheat proteins.

The current results stand in contrast to much of the literature. Li et al. (2008) reported improved growth in turbot, which had an initial weight of $151.3 \pm 11.3 \mathrm{~g}$, when fed a pelleted diet supplemented with a commercial yeast product (containing 20\% b-glucan and 20\% MOS, $1.3 \mathrm{~g} \mathrm{~kg}^{-1}$ in diet) for 72 days. However, SGR results $(0.75-0.84 \%$ day $^{-1}$ ) were in general low compared to values $\left(1.39-1.46 \%\right.$ day $\left.^{-1}\right)$ in this study. Yoo et al. (2007) also observed a positive effect on weight gain, SGR and feed efficiency ratio in olive flounder (Paralichthys olivaceus) which was fed diets containing yeast b-glucan, derived from Saccharomyces cerevisiae, for 7 weeks. Growth performance was highest at 1 and $1.5 \mathrm{~g} \mathrm{~kg}^{-1} \mathrm{~b}$-glucan inclusion which is similar to the concentration of $6 \mathrm{~g} \mathrm{~kg}^{-1} \mathrm{GM}$ (20\% b-glucan/17\% MOS) applied in this study in one of the diets. However, fish had an initial weight of $9.2 \mathrm{~g}$ and were much smaller compared to turbots in this study. Likewise, improved weight gain, SGR and FCR were reported in mirror carp (Cyprinus carpio) fed a diet with levels of 10 and $20 \mathrm{~g} \mathrm{~kg}^{-1}$ yeast b-glucan (Kühlwein et al., 2014). Dietary yeast MOS ( 2 and $4 \mathrm{~g} \mathrm{~kg}^{-1}$ diet) enhanced growth performance in European sea bass (Dicentrarchus labrax) and promoted growth, FCR and survival in rainbow trout (Oncorhynchus mykiss) (Staykov et al., 2007; Torrecillas et al., 2012).
Further investigations observed growth enhancing properties using extracts of brown algae or yeast derived nucleotides as diet additives. Dietary inclusion of algae extracts ( $5 \mathrm{~g} \mathrm{~kg}^{-1}$ diet) and yeast nucleotides ( 1.5 and $2 \mathrm{~g} \mathrm{~kg}^{-1}$ diet) had a positive effect on performances in beluga (Huso huso), malabar grouper (Epinephelus malabaricus), Atlantic salmon (Salmo salar) and rainbow trout (Ahmadifar et al., 2009; Burrells et al., 2001b; Heidarieh et al., 2011, 2012; Lin et al., 2009; Tahmasebi-Kohyani et al., 2012). Other studies demonstrated that inclusion of potassium diformate ( 2 and $3 \mathrm{~g} \mathrm{~kg}^{-1}$ diet) and probiotic Bacillus strains (B. subtilis and/or B. licheniformis) stimulated growth in nile tilapia (Oreochromis niloticus), rohu (Labeo rohita), carp and trout (Abu Elala and Ragaa, 2014; Bagheri et al., 2008; He et al., 2011; Kumar et al., 2006).

In contrast, some investigations could not confirm a positive performance of diet additives in other fish species. Research demonstrated that b-glucan or MOS enriched diets did not improve growth in dentex (Dentex dentex), tilapia, Asian catfish (Clarias batrachus), channel catfish (Ictalurus punctatus), hybrid tilapia (O. niloticus 우 $\times 0$. aureus $0^{7}$ ) and Atlantic salmon (Efthimiou, 1996; Grisdale-Helland et al., 2008; He et al., 2009; Kumari and Sahoo, 2006; Lara-Flores et al., 2003; Welker et al., 2007; Whittington et al., 2005). Moreover, supplementation with brown algae extracts, yeast nucleotides and potassium diformate did not support growth compared to the unsupplemented diets in red drum (Sciaenops ocellatus) and tilapia (Li et al., 2005; Merrifield et al., 2011; Zhou et al., 2009).

Refstie et al. (2010) proved that supplementation with MOS ( $2 \mathrm{~g} \mathrm{~kg}^{-1}$ diet) in a FM reduced diet, containing soy bean and sunflower meal (SBM + SFM) as substitutes, improved growth performance in salmon. However, the same MOS concentration in a SBM diet and bglucan ( 0.5 and $1 \mathrm{~g} \mathrm{~kg}^{-1}$ diet) inclusion in both SBM + SFM and SBM diets fail to increase the potential of both PP-based diets. Similarly, growth performance and feed utilization of turbot and gilthead sea bream (Sparus aurata) remained unaffected by nucleotide ( 0.3 and $1 \mathrm{~g} \mathrm{~kg}^{-1}$ diet) and MOS ( 2 and $4 \mathrm{~g} \mathrm{~kg}^{-1}$ diet) supplementation in a FM- and SBM-based diet (Dimitroglou et al., 2010; Peng et al., 2013).

In the present study, turbots have fed on high quality diets in trial I and have been reared under optimal conditions during the experiment. Although diet additives did not improve growth performance under favorable rearing conditions, these additives may have beneficial impacts

Table 4

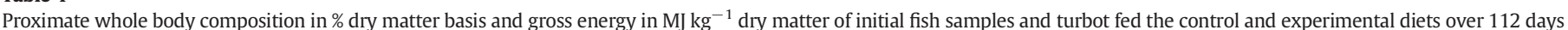
in trial 1.

\begin{tabular}{|c|c|c|c|c|c|c|c|}
\hline & Initial fish $(n=10)$ & $\mathrm{CT}$ & GM & $A C$ & NR & PDF & BS \\
\hline \multicolumn{8}{|c|}{ Proximate body composition } \\
\hline Dry matter & 21.2 & $20.3 \pm 1.5$ & $21.1 \pm 0.4$ & $23.3 \pm 3.3$ & $22.9 \pm 1.3$ & $24.2 \pm 0.3$ & $24.3 \pm 0.3$ \\
\hline Crude protein & 65.4 & $72.2 \pm 3.9$ & $71.9 \pm 3.3$ & $70.5 \pm 2.5$ & $71.6 \pm 3.0$ & $72.3 \pm 2.0$ & $69.7 \pm 1.1$ \\
\hline Crude lipid & 14.5 & $11.2 \pm 4.4$ & $13.4 \pm 3.7$ & $13.5 \pm 3.8$ & $12.1 \pm 0.8$ & $12.2 \pm 3.4$ & $13.7 \pm 0.8$ \\
\hline Crude ash & 17.6 & $17.6 \pm 1.0$ & $14.7 \pm 0.9$ & $16.7 \pm 1.9$ & $15.7 \pm 1.0$ & $16.7 \pm 2.7$ & $16.2 \pm 0.1$ \\
\hline Gross energy ( $\mathrm{MJ} \mathrm{kg}^{-1}$ ) & 21.3 & $20.0 \pm 1.4$ & $20.9 \pm 1.4$ & $21.3 \pm 0.9$ & $20.5 \pm 0.2$ & $20.5 \pm 1.7$ & $21.5 \pm 0.8$ \\
\hline
\end{tabular}

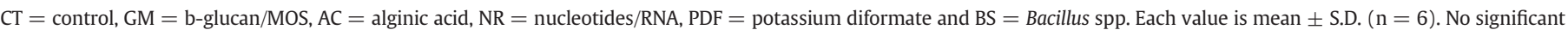
differences were identified $(\mathrm{p}>0.05$ ). 
Table 5

Growth performance and feed utilization of turbot fed experimental diets for 84 days in trial 2 .

\begin{tabular}{|c|c|c|c|c|c|c|}
\hline & C-HF & C-LF & GM & $A C$ & NR & BS \\
\hline Initial weight, $\mathrm{g}$ & $95.8 \pm 0.1$ & $95.8 \pm 0.1$ & $95.9 \pm 0.8$ & $95.9 \pm 0.2$ & $95.9 \pm 0.3$ & $95.7 \pm 0.1$ \\
\hline Final weight, g & $299.5 \pm 92.0^{\mathrm{a}}$ & $254.2 \pm 77.9^{\mathrm{b}}$ & $251.9 \pm 69.6^{\mathrm{b}}$ & $257.5 \pm 70.4^{b}$ & $246.3 \pm 71.1^{b}$ & $254.0 \pm 72.0^{\mathrm{b}}$ \\
\hline Weight gain, $\mathrm{g}$ & $203.7 \pm 21.8^{\mathrm{a}}$ & $158.4 \pm 32.2^{\mathrm{b}}$ & $156.1 \pm 19.7^{\mathrm{b}}$ & $161.4 \pm 16.7^{b}$ & $150.3 \pm 15.3^{\mathrm{b}}$ & $158.6 \pm 20.8^{\mathrm{b}}$ \\
\hline SGR, $\%$ day $^{-1}$ & $1.35 \pm 0.09^{\mathrm{a}}$ & $1.15 \pm 0.15^{\mathrm{b}}$ & $1.15 \pm 0.09^{\mathrm{b}}$ & $1.17 \pm 0.08^{\mathrm{b}}$ & $1.12 \pm 0.08^{\mathrm{b}}$ & $1.16 \pm 0.10^{\mathrm{b}}$ \\
\hline DFI, \% day ${ }^{-1}$ & $0.95 \pm 0.05$ & $0.86 \pm 0.07$ & $0.88 \pm 0.06$ & $0.85 \pm 0.08$ & $0.86 \pm 0.05$ & $0.89 \pm 0.05$ \\
\hline FCR & $0.78 \pm 0.01$ & $0.81 \pm 0.04$ & $0.83 \pm 0.08$ & $0.79 \pm 0.09$ & $0.82 \pm 0.03$ & $0.83 \pm 0.07$ \\
\hline Mortality, \% & 0.0 & 0.0 & 0.7 & 0.0 & 0.7 & 0.0 \\
\hline $\mathrm{K}, \%$ & $2.07 \pm 0.04$ & $2.01 \pm 0.07$ & $2.00 \pm 0.06$ & $1.99 \pm 0.10$ & $2.03 \pm 0.05$ & $1.97 \pm 0.08$ \\
\hline HSI, \% & $1.19 \pm 0.14$ & $1.25 \pm 0.17$ & $1.36 \pm 0.20$ & $1.28 \pm 0.26$ & $1.21 \pm 0.19$ & $1.40 \pm 0.19$ \\
\hline
\end{tabular}

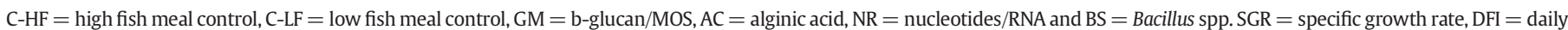

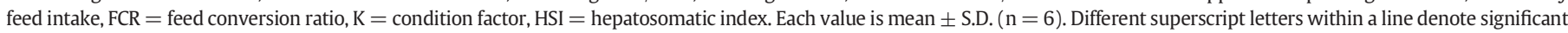
differences $(\mathrm{p}<0.05)$.

on fish in challenging situations, for instance under conditions of immunodepression related to environmental stress, as demonstrated in previous studies (Burrells et al., 2001b; El-Boshy et al., 2010; Kumar et al., 2006; Santarém et al., 1997; Tahmasebi-Kohyani et al., 2012; Torrecillas et al., 2012; Yeh et al., 2008). Some authors hypothesize that these functional additives are able to enhance mechanism of the immune system that in turn leads to resistance against pathogens and diseases (Dalmo and Bøgwald, 2008; Merrifield et al., 2010; Ringø et al., 2012).

Survival, achieved SGR and FCR of turbots feeding FM-based diets and PP-based diets were higher or similar compared to those observed in other studies (Árnason et al., 2009; Bonaldo et al., 2011; Regost et al., 1999; Schram et al., 2009; Van Ham et al., 2003). Decreased growth may be caused by a deficiency of phosphorous in diets or by poor utilization of plant proteins offered and a limitation of essential amino acids. In general, reduced DFI for diets high in plant proteins indicate that these are less attractive and palatable than diet treatments containing a high level of FM. Further investigations can confirm performance loss and reduced feed intake in turbots with increasing PP content in diets containing overall crude protein levels of 50-54\% (Regost et al., 1999), 53-51\% (Bonaldo et al., 2011), 50\% (Day and Plascencia González, 2000), 57-62\% (Fournier et al., 2004) and 59\% (Nagel et al., 2012).

Researchers suggest that palatability (Arndt et al., 1999; Freitas et al., 2011; Kissil et al., 2000), lack of nutrients (Gatlin et al., 2007), unfavorable amino acid profiles (Li et al., 2008) and antinutritional factors (ANFs) (Francis et al., 2001) of plant meals or concentrates are responsible for reduced feed intake and poor feed conversion in fish species. This may explain performance loss of turbots fed PP-based diets in this study. Previous studies already revealed negative effects of diets containing soy bean meal (SBM) or soy protein concentrate (SPC) on feed consumption and growth performance in turbot (Bonaldo et al., 2011; Day and Plascencia González, 2000) and other fish species (Davis et al., 2005; Kasper et al., 2007; Kaushik et al., 1995; Kissil et al., 2000). However, during the process of SPC production most antinutritional factors should be destroyed, only phytate may be concentrated with the protein fraction (Gatlin et al., 2007). High phytate concentrations reduce the availability of phosphorus as it is bound in or by phytic acid. It seems possible that a limitation of phosphorus and/or essential amino acids (EAAs, e.g. lysine) is responsible for reduced growth rates in turbots (Kaushik, 1998; Peres and Oliva-Teles, 2008; Riche and Brown, 1996).

Whole body composition of turbots remained unaffected by additive inclusions in both, high and low FM diets as in earlier studies comparing FM- or PP-based diets supplemented with some additives (Dimitroglou et al., 2010; Heidarieh et al., 2012; Kühlwein et al., 2014; Merrifield et al., 2011; Ng et al., 2009). The observed growth decline of fish fed high levels of soy bean and wheat proteins cannot be explained by reduced development of fillet muscles caused by lower protein retention or reduced fat storage. In contrast, other authors observed an influence of additives on crude lipid (Baruah et al., 2007; Li et al., 2005) or crude protein and lipid content (Abdel-Tawwab et al., 2008; Bagheri et al., 2008; Bairagi et al., 2004; Lara-Flores et al., 2003) in whole body composition. Additive and PP inclusion also did not influence HSI values and, consequently, did not seem to promote an increased or decreased fat retention in liver. Liver index of Senegalese sole (Solea senegalensis) was higher in fish fed a PP-based diet compared to FM-based diets, although HSI decreased with reduced fat content in FM diets (Valente et al., 2011). However, no evidence of increased fat storage in liver was found in other fish species feeding high levels of PP (Chatzifotis et al., 2008; Dimitroglou et al., 2010; Hansen et al., 2013; Lekva et al., 2010).

At present, there is no single definite mode of action and explanation of why or how dietary supplementation with the examined additives causes improved growth in aquatic animals and it is not clear why they affect growth in some species and not in others. Besides, additives that have been successful at improving growth performance in one study proved to be ineffective for the same species in another investigation. The potential effect may depend on the dosage of additives applied and the method of administration, short- or long-term and oral, immersion or injection (Anderson and Siwicki, 1994; Dalmo and Bøgwald, 2008; Jeney and Anderson, 1993; Nikl et al., 1993; Peddie et al., 2002; Selvaraj et al., 2005). In addition, culture conditions, for instance physical and chemical water parameters, stocking density and feeding rate, as well as size and age class have an influence on performances in turbot and have to be considered when comparing results (Blanquet and Oliva-Teles, 2010; Foss et al., 2009; Imsland et al., 2001; Irwin et al.,

Table 6

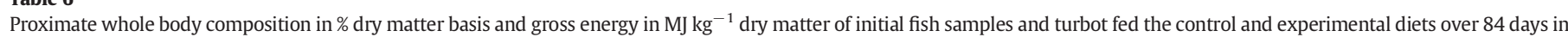
trial 2.

\begin{tabular}{|c|c|c|c|c|c|c|c|}
\hline & Initial fish $(\mathrm{n}=10)$ & $\mathrm{C}-\mathrm{HF}$ & C-LF & GM & AC & NR & BS \\
\hline \multicolumn{8}{|c|}{ Proximate body composition } \\
\hline Dry matter & 20.4 & $25.1 \pm 6.3$ & $20.4 \pm 1.7$ & $21.5 \pm 0.4$ & $20.7 \pm 1.8$ & $22.0 \pm 1.0$ & $19.0 \pm 5.2$ \\
\hline Crude protein & 72.8 & $68.3 \pm 2.3$ & $69.7 \pm 2.7$ & $71.6 \pm 1.8$ & $72.0 \pm 3.3$ & $67.2 \pm 5.1$ & $72.5 \pm 0.4$ \\
\hline Crude lipid & 4.4 & $12.0 \pm 2.6$ & $12.4 \pm 2.3$ & $13.1 \pm 3.1$ & $12.0 \pm 4.8$ & $15.6 \pm 2.3$ & $13.8 \pm 1.6$ \\
\hline Crude ash & 23.4 & $18.1 \pm 2.4$ & $17.7 \pm 2.4$ & $15.4 \pm 1.0$ & $16.5 \pm 1.2$ & $16.6 \pm 3.2$ & $15.0 \pm 1.2$ \\
\hline Gross energy ( $\mathrm{MJ} \mathrm{kg}{ }^{-1}$ ) & 17.5 & $20.9 \pm 0.6$ & $20.8 \pm 1.1$ & $21.7 \pm 0.6$ & $21.6 \pm 1.2$ & $21.5 \pm 1.0$ & $21.8 \pm 0.9$ \\
\hline
\end{tabular}

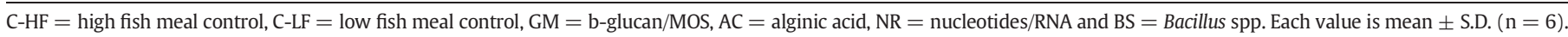

No significant differences were identified $(\mathrm{p}>0.05)$. 
1999; van Bussel et al., 2012; Van Ham et al., 2003). Under optimal holding conditions, diet additives probably do not have beneficial impacts in turbot during the grow-out phase. However, additives may be valuable growth and immunity promoters, especially in earlier life stages of fish, to improve survival during critical life phases and to overcome environmental stressors in fish farms. In particular, there is still a dearth of information about the effects of diet additives on performances in fish of size classes above $200 \mathrm{~g}$ and in fish that have been offered additives over a long-term period more than 4 months.

In conclusion, diet additives (yeast BG/MOS, yeast nucleotides/RNA, alginic acid, potassium diformate and strains of Bacillus spp.) failed to improve growth performance and feed utilization in turbots, weighing between 50 and $250 \mathrm{~g}$, fed FM-based diets (78\% FM) in RAS holding. Likewise, yeast BG/MOS, yeast nucleotides/RNA, alginic acid and strains of Bacillus spp. failed to improve growth and feed conversion in turbots (100-250 g) offering PP-based diets which contain 25\% SPC and 15\% wheat gluten. Reduced growth performance due to 45\% FM protein substitution can partially be explained by a deficiency of calcium and phosphorus and some EAAs in PP-based diets resulting in decreased protein turnover. Results indicate that these additives are not economically viable for inclusion in commercial turbot on-growing diets when culturing turbots under optimal conditions. Further research is required to determine the size and level of optimal conditions where additives become superfluous.

\section{Acknowledgments}

This study was supported by the Federal Ministry of Food, Agriculture and Consumer Protection (BMELV, "Programm Innovationsförderung") via the Federal Office for Agriculture and Food (BLE).

The authors are grateful to Michael Lutz (Köster Marine Proteins), Matthias Seidel (J. Müller Weser) and Andreas Wohltmann (Vereinigte Fischmehlwerke Cuxhaven) for providing the feed ingredients and for enabling this study. The provision of diet additives (Intervet/ScheringPlough Aquaculture, Chemoforma Ltd. and ADDCON/Nordic AS) was also highly appreciated. We also thank Christof Kunert (Intertek) for the support by analyzing fatty acids and the proximate composition of experimental diets and fish bodies as well as Sabine Strieben for her cooperation during the laboratory work and Marcus Thon/Kai Lorkowski for their technical support. The authors wish to thank the two anonymous reviewers for their constructive help in improving the manuscript.

\section{References}

Abdel-Tawwab, M., Abdel-Rahman, A.M., Ismael, N.E.M., 2008. Evaluation of commercial live bakers' yeast, Saccharomyces cerevisiae as a growth and immunity promoter for Fry Nile tilapia, Oreochromis niloticus (L.) challenged in situ with Aeromonas hydrophila. Aquaculture 280, 185-189.

Abu Elala, N.M., Ragaa, N.M., 2014. Eubiotic effect of a dietary acidifier (potassium diformate) on the health status of cultured Oreochromis niloticus. J. Adv. Res. http:// dx.doi.org/10.1016/j.jare.2014.02.008

Ahmadifar, E., Jalali, M.A., Soudagar, M., Azari, T.G., Mohammadi, Z.A.A., 2009. Effects of Aquavac Ergosan on growth performance, survival and haematological factors in beluga (Huso huso) juvenile. J. Agric. Sci. Nat. Resour. 16 (unpaginated).

Ai, Q., Mai, K., Zhang, L., Tan, B., Zhang, W., Xu, W., Li, H., 2007. Effects of dietary $\beta-1,3$ glucan on innate immune response of large yellow croaker, Pseudosciaena crocea. Fish Shellfish Immunol. 22, 394-402.

Anderson, D.P., Siwicki, A.K., 1994. Duration of Protection against Aeromonas salmonicida in brook trout immunostimulated with glucan or chitosan by injection or immersion. Prog. Fish Cult. 56, 258-261.

Andrews, S.R., Sahu, N.P., Pal, A.K., Kumar, S., 2009. Haematological modulation and growth of Labeo rohita fingerlings: effect of dietary mannan oligosaccharide, yeast extract, protein hydrolysate and chlorella. Aquacult. Res. 41, 61-69.

Árnason, T., Björnsson, B., Steinarsson, A., Oddgeirsson, M., 2009. Effects of temperature and body weight on growth rate and feed conversion ratio in turbot (Scophthalmus maximus). Aquaculture 295, 218-225.

Arndt, R.E., Hardy, R.W., Sugiura, S.H., Dong, F.M., 1999. Effects of heat treatment and substitution level on palatability and nutritional value of soy defatted flour in feeds for Coho Salmon, Oncorhynchus kisutch. Aquaculture 180, 129-145.

Bagheri, T., Hedayati, S.A., Yavari, V., Alizade, M., Farzanfar, A., 2008. Growth, surviva and gut microbial load of rainbow trout (Onchorhynchus mykiss) fry given diet supplemented with probiotic during the two months of first feeding. Turk. J. Fish. Aquat. Sci. 43-48

Bairagi, A., Sarkar Ghosh, K., Sen, S.K., Ray, A.K., 2004. Evaluation of the nutritive value of Leucaena leucocephala leaf meal, inoculated with fish intestinal bacteria Bacillus subtilis and Bacillus circulans in formulated diets for rohu, Labeo rohita (Hamilton) fingerlings. Aquacult. Res. 35, 436-446.

Bakke-McKellep, A.M., Refstie, S., 2008. Alternative protein sources and digestive function alterations in teleost fishes. In: Cyrino, J.E.P., Roubach, R., Bureau, D., Kapoor, B.G. (Eds.), Feeding and Digestive Functions of Fishes. Science Publishers, Inc., Enfield, NH, USA, pp. 445-478.

Balcázar, J.L., Blas, I.d., Ruiz-Zarzuela, I., Cunningham, D., Vendrell, D., Múzquiz, J.L., 2006. The role of probiotics in aquaculture. Vet. Microbiol. 114, 173-186.

Baruah, K., Sahu, N.P., Pal, A.K., Jain, K.K., Debnath, D., Mukherjee, S.C., 2007. Dietary microbial phytase and citric acid synergistically enhances nutrient digestibility and growth performance of Labeo rohita (Hamilton) juveniles at sub-optimal protein level. Aquacult. Res. 38, 109-120.

Blanquet, I., Oliva-Teles, A., 2010. Effect of feed restriction on the growth performance of turbot (Scophthalmus maximus L.) juveniles under commercial rearing conditions. Aquacult. Res. 41, 1255-1260.

Bohn, J.A., BeMiller, J.N., 1995. ( $1 \rightarrow 3)-\beta-D-G l u c a n s$ as biological response modifiers: a review of structure-functional activity relationships. Carbohydr. Polym. 28, 3-14.

Bonaldo, A., Parma, L., Mandrioli, L., Sirri, R., Fontanillas, R., Badiani, A., Gatta, P.P., 2011. Increasing dietary plant proteins affects growth performance and ammonia excretion but not digestibility and gut histology in turbot (Psetta maxima) juveniles. Aquaculture 318, 101-108.

Buchholz, C., Krause, G., Buck, B.H., 2012. Seaweed and man. In: Wiencke, C., Bischof, K. (Eds.), Springer. Berlin, Heidelberg, pp. 471-493.

Burrells, C., Williams, P.D., Forno, P.F., 2001a. Dietary nucleotides: a novel supplement in fish feeds: 1. Effects on resistance to disease in salmonids. Aquaculture 199, 159-169.

Burrells, C., Williams, P.D., Southgate, P.J., Wadsworth, S.L., 2001b. Dietary nucleotides: a novel supplement in fish feeds: 2 . Effects on vaccination, salt water transfer, growth rates and physiology of Atlantic salmon (Salmo salar L.). Aquaculture 199, 171-184.

Carver, J.D., Walker, W.A., 1995. The role of nucleotides in human nutrition. J. Nutr. Biochem. 6, 58-72.

Chatzifotis, S., Polemitou, I., Divanach, P., Antonopoulou, E., 2008. Effect of dietary taurine supplementation on growth performance and bile salt activated lipase activity of common dentex, Dentex dentex, fed a fish meal/soy protein concentrate-based diet. Aquaculture 275, 201-208.

Cho, S.H., Lee, S.M., Lee, S.M., Lee, J.H., 2005. Effect of dietary protein and lipid levels on growth and body composition of juvenile turbot (Scophthalmus maximus L) reared under optimum salinity and temperature conditions. Aquacult. Nutr. 11, 235-240.

Dalmo, R.A., Bøgwald, J., 2008. ß-Glucans as conductors of immune symphonies. Fish and Shellfish Immunol. 25, 384-396.

Dalsgaard, J., Lund, I., Thorarinsdottir, R., Drengstig, A., Arvonen, K., Pedersen, P.B., 2013. Farming different species in RAS in Nordic countries: current status and future perspectives. Aquacult. Eng. 53, 2-13.

Davis, D.A., Miller, C.L., Phelps, R.P., 2005. Replacement of fish meal with soybean meal in the production diets of juvenile red snapper, Lutjanus campechanus. J. World Aquacult. Soc. 36, 114-119.

Day, O.J., Plascencia González, H.G., 2000. Soybean protein concentrate as a protein source for turbot Scophthalmus maximus L. Aquacult. Nutr. 6, 221-228.

Dimitroglou, A., Merrifield, D.L., Spring, P., Sweetman, J., Moate, R., Davies, S.J., 2010. Effects of mannan oligosaccharide (MOS) supplementation on growth performance, feed utilisation, intestinal histology and gut microbiota of gilthead sea bream (Sparus aurata). Aquaculture 300, 182-188

Efthimiou, S., 1996. Dietary intake of $\beta-1,3 / 1,6$ glucans in juvenile dentex (Dentex dentex), Sparidae: effects on growth performance, mortalities and non-specific defense mechanisms. J. Appl. Ichthyol. 12, 1-7.

El-Boshy, M.E., El-Ashram, A.M., AbdelHamid, F.M., Gadalla, H.A., 2010. Immunomodulatory effect of dietary Saccharomyces cerevisiae, $\beta$-glucan and laminaran in mercuric chloride treated Nile tilapia (Oreochromis niloticus) and experimentally infected with Aeromonas hydrophila. Fish and Shellfish Immunol. 28, 802-808.

FAO, 2014. Psetta maxima (Linnaeus, 1758). Statistical information. Global Aquaculture Production 1950-2012. Fisheries and Aquaculture Department, Rome, Italy (http:// www.fao.org/fishery/statistics/global-aquaculture-production/query/en).

Fleurence, J., 1999. Seaweed proteins: biochemical, nutritional aspects and potential uses. Trends Food Sci. Technol. 10, 25-28.

Foss, A., Imsland, A.K., Roth, B., Schram, E., Stefansson, S.O., 2009. Effects of chronic and periodic exposure to ammonia on growth and blood physiology in juvenile turbot (Scophthalmus maximus). Aquaculture 296, 45-50.

Fournier, V., Huelvan, C., Desbruyeres, E., 2004. Incorporation of a mixture of plant feedstuffs as substitute for fish meal in diets of juvenile turbot (Psetta maxima). Aquaculture 236, 451-465

Francis, G., Makkar, H.P.S., Becker, K., 2001. Antinutritional factors present in plant-derived alternate fish feed ingredients and their effects in fish. Aquaculture 199, 197-227.

Freitas, L.E.L., Nunes, A.J.P., do Carmo Sá, M.V., 2011. Growth and feeding responses of the mutton snapper, Lutjanus analis (Cuvier 1828), fed on diets with soy protein concentrate in replacement of Anchovy fish meal. Aquacult. Res, 42, 866-877.

Gatlin III, D.M., Barrows, F.T., Brown, P., Dabrowski, K., Gaylord, T.G., Hardy, R.W., Herman, E., Hu, G., Krogdahl, Å., Nelson, R., Overturf, K., Rust, M., Sealey, W., Skonberg, D., Souza, J.E., Stone, D., Wilson, R., Wurtele, E., 2007. Expanding the utilization of sustainable plant products in aquafeeds: a review. Aquacult. Res. 38, 551-579.

Grisdale-Helland, B., Helland, S.J., Gatlin Iii, D.M., 2008. The effects of dietary supplementation with mannanoligosaccharide, fructooligosaccharide or galactooligosaccharide on the growth and feed utilization of Atlantic salmon (Salmo salar). Aquaculture $283,163-167$. 
Gupta, S., Abu-Ghannam, N., 2011. Bioactive potential and possible health effects of edible brown seaweeds. Trends Food Sci. Technol. 22, 315-326.

Hansen, A.C., Rosenlund, G., Karlsen, Ø., Olsen, R.E., Hemre, G.I., 2013. Marine ashproducts influence growth and feed utilization when Atlantic cod Gadus morhua L. are fed plant-based diets. J. Appl. Ichthyol. 29, 532-540.

Hardy, R.W., 2010. Utilization of plant proteins in fish diets: effects of global demand and supplies of fishmeal. Aquacult. Res. 41, 770-776.

He, S., Zhou, Z., Liu, Y., Shi, P., Yao, B., Ringø, E., Yoon, I., 2009. Effects of dietary Saccharomyces cerevisiae fermentation product (DVAQUA®) on growth performance, intestinal autochthonous bacterial community and non-specific immunity of hybrid tilapia (Oreochromis niloticus 우 $\times 0$. aureus $\sigma^{7}$ ) cultured in cages. Aquaculture 294, 99-107.

He, S., Liu, W., Zhou, Z., Mao, W., Ren, P., Marubashi, T., Ringø, E., 2011. Evaluation of probiotic strain bacillus subtilis C-3102 as a feed supplement for koi carp (Cyprinus carpio). J. Aquacult. Res. Dev. S1-005.

Heidarieh, M., Soltani, M., Tamimi, A.H., Toluei, M.H., 2011. Comparative effect of raw fiber (Vitacel) and alginic acid (Ergosan) on growth performance, immunocompetent cell population and plasma lysozyme content of giant sturgeon (Huso huso). Turk. J. Fish. Aquat. Sci. 11, 445-450.

Heidarieh, M., Mirvaghefi, A., Akbari, M., Farahmand, H., Sheikhzadeh, N., Shahbazfar, A. Behgar, M., 2012. Effect of dietary Ergosan on growth performance, digestive enzymes, intestinal histology, hematological parameters and body composition of rainbow trout (Oncorhynchus mykiss). Fish Physiol. Biochem. 38, 1169-1174.

Holdt, S.L., Kraan, S., 2011. Bioactive compounds in seaweed: functional food applications and legislation. J. Appl. Phycol. 23, 543-597.

Hossain, M.A., Pandey, A., Satoh, S., 2007. Effects of organic acids on growth and phosphorus utilization in red sea bream Pagrus major. Fish. Sci. 73, 1309-1317.

Imsland, A.K., Foss, A., Gunnarsson, S., Berntssen, M.H.G., FitzGerald, R., Wendelaar Bonga, S., Ham, E.v., Nævdal, G., Stefansson, S.O., 2001. The interaction of temperature and salinity on growth and food conversion in juvenile turbot (Scophthalmus maximus). Aquaculture 198, 353-367.

Irwin, S., O'Halloran, J., FitzGerald, R.D., 1999. Stocking density, growth and growth variation in juvenile turbot, Scophthalmus maximus (Rafinesque). Aquaculture 178, 77-88.

Jeney, G., Anderson, D.P., 1993. Glucan injection or bath exposure given alone or in combination with a bacterin enhance the non-specific defence mechanisms in rainbow trout (Oncorhynchus mykiss). Aquaculture 116, 315-329.

Kasper, C.S., Watkins, B.A., Brown, P.B., 2007. Evaluation of two soybean meals fed to yellow perch (Perca flavescens). Aquacult. Nutr. 13, 431-438

Kaushik, S.J., 1998. Whole body amino acid composition of European seabass (Dicentrarchus labrax), gilthead seabream (Sparus aurata) and turbot (Psetta maxima) with an estimation of their IAA requirement profiles. Aquat. Living Resour. 11, 355-358.

Kaushik, S.J., Cravedi, J.P., Lalles, J.P., Sumpter, J., Fauconneau, B., Laroche, M., 1995. Partial or total replacement of fish meal by soybean protein on growth, protein utilization, potential estrogenic or antigenic effects, cholesterolemia and flesh quality in rainbow trout, Oncorhynchus mykiss. Aquaculture 133, 257-274.

Kesarcodi-Watson, A., Kaspar, H., Lategan, M.J., Gibson, L., 2008. Probiotics in aquaculture: the need, principles and mechanisms of action and screening processes. Aquaculture 274, 1-14.

Kissil, G.W., Lupatsch, I., Higgs, D.A., Hardy, R.W., 2000. Dietary substitution of soy and rapeseed protein concentrates for fish meal, and their effects on growth and nutrient utilization in gilthead seabream Sparus aurata L. Aquacult. Res. 31, 595-601.

Krogdahl, A., Penn, M., Thorsen, J., Refstie, S., Bakke, A.M., 2010. Important antinutrients in plant feedstuffs for aquaculture: an update on recent findings regarding responses in salmonids. Aquacult. Res. 41, 333-344.

Kühlwein, H., Merrifield, D.L., Rawling, M.D., Foey, A.D., Davies, S.J., 2014. Effects of dietary $\beta-(1,3)(1,6)$-D-glucan supplementation on growth performance, intestinal morphology and haemato-immunological profile of mirror carp (Cyprinus carpio L.). J. Anim. Physiol. Anim. Nutr. 98, 279-289.

Kumar, R., Mukherjee, S.C., Prasad, K.P., Pal, A.K., 2006. Evaluation of Bacillus subtilis as a probiotic to Indian major carp Labeo rohita (Ham.). Aquacult. Res. 37, 1215-1221.

Kumari, J., Sahoo, P.K., 2006. Dietary $\beta-1,3$ glucan potentiates innate immunity and disease resistance of Asian catfish, Clarias batrachus (L.). J. Fish Dis. 29, 95-101.

Lara-Flores, M., Olvera-Novoa, M.A., Guzmán-Méndez, B.z.E., López-Madrid, W., 2003. Use of the bacteria Streptococcus faecium and Lactobacillus acidophilus, and the yeast Saccharomyces cerevisiae as growth promoters in Nile tilapia (Oreochromis niloticus). Aquaculture 216, 193-201.

Lee, J.K., Cho, S.H., Park, S.U., Kim, K.D., Lee, S.M., 2003. Dietary protein requirement for young turbot (Scophthalmus maximus L.). Aquacult. Nutr. 9, 283-286.

Lekva, A., Hansen, A.-C., Rosenlund, G., Karlsen, Ø., Hemre, G.-I., 2010. Energy dilution with $\alpha$-cellulose in diets for Atlantic cod (Gadus morhua L.) juveniles - effects on growth, feed intake, liver size and digestibility of nutrients. Aquaculture 300, 169-175.

Li, P., Gatlin III, D.M., 2006. Nucleotide nutrition in fish: current knowledge and future applications. Aquaculture 251, 141-152.

Li, P., Burr, G.S., Goff, J., Whiteman, K.W., Davis, K.B., Vega, R.R., Neill, W.H., Gatlin Iii, D.M., 2005. A preliminary study on the effects of dietary supplementation of brewers yeast and nucleotides, singularly or in combination, on juvenile red drum (Sciaenops ocellatus). Aquacult. Res. 36, 1120-1127.

Li, Y., Wang, Y.J., Wang, L., Jiang, K.Y., 2008. Influence of several non-nutrient additives on nonspecific immunity and growth of juvenile turbot, Scophthalmus maximus L. Aquacult. Nutr. 14, 387-395.

Lin, Y.H., Wang, H., Shiau, S.Y., 2009. Dietary nucleotide supplementation enhances growth and immune responses of grouper, Epinephelus malabaricus. Aquacult. Nutr. $15,117-122$.

Lückstädt, C., 2008. The use of acidifiers in fish nutrition. CAB Rev. 3.

MacArtain, P., Gill, C.I.R., Brooks, M., Campbell, R., Rowland, I.R., 2007. Nutritional value of edible seaweeds. Nutr. Rev. 65, 535-543.
Meena, D.K., Das, P., Kumar, S., Mandal, S.C., Prusty, A.K., Singh, S.K., Akhtar, M.S., Behera, B.K Kumar, K., Pal, A.K., Mukherjee, S.C., 2013. Beta-glucan: an ideal immunostimulant in aquaculture (a review). Fish Physiol. Biochem. 39, 431-457.

Merrifield, D.L., Dimitroglou, A., Foey, A., Davies, S.J., Baker, R.T.M., Bøgwald, J., Castex, M. Ringø, E., 2010. The current status and future focus of probiotic and prebiotic applications for salmonids. Aquaculture 302, 1-18.

Merrifield, D.L., Harper, G.M., Mustafa, S., Carnevali, O., Picchietti, S., Davies, S.J., 2011 Effect of dietary alginic acid on juvenile tilapia (Oreochromis niloticus) intestinal microbial balance, intestinal histology and growth performance. Cell Tissue Res. 344, 135-146.

Misra, C.K., Das, B.K., Mukherjee, S.C., Pattnaik, P., 2006. Effect of long term administration of dietary $\beta$-glucan on immunity, growth and survival of Labeo rohita fingerlings. Aquaculture 255, 82-94.

Nagel, F., von Danwitz, A., Tusche, K., Kroeckel, S., van Bussel, C.G.J., Schlachter, M., Adem, H., Tressel, R.-P., Schulz, C., 2012. Nutritional evaluation of rapeseed protein isolate as fish meal substitute for juvenile turbot (Psetta maxima L.) - impact on growth performance, body composition, nutrient digestibility and blood physiology. Aquaculture 356-357, 357-364.

Ng, W.-K., Koh, C.-B., Sudesh, K., Siti-Zahrah, A., 2009. Effects of dietary organic acids on growth, nutrient digestibility and gut microflora of red hybrid tilapia, Oreochromis sp., and subsequent survival during a challenge test with Streptococcus agalactiae. Aquacult. Res, 40, 1490-1500.

Nikl, L., Evelyn, T.P.T., Albright, L.J., 1993. Trials with an orally and immersionadministered beta-1,3 glucan as an immunoprophylactic against Aeromonas salmonicida in juvenile chinook salmon Oncorhynchus tshawytscha. Dis. Aquat. Org. 17, 191-196.

Peddie, S., Zou, J., Secombes, C.J., 2002. Immunostimulation in the rainbow trout (Oncorhynchus mykiss) following intraperitoneal administration of Ergosan. Vet. Immunol. Immunopathol. 86, 101-113.

Peng, M., Xu, W., Ai, Q., Mai, K., Liufu, Z., Zhang, K., 2013. Effects of nucleotide supplementation on growth, immune responses and intestinal morphology in juvenile turbot fed diets with graded levels of soybean meal (Scophthalmus maximus L.). Aquaculture 392-395, 51-58.

Peres, H., Oliva-Teles, A., 2008. Lysine requirement and efficiency of lysine utilization in turbot (Scophthalmus maximus) juveniles. Aquaculture 275, 283-290.

Raida, M.K., Larsen, J.L., Nielsen, M.E., Buchmann, K., 2003. Enhanced resistance of rainbow trout, Oncorhynchus mykiss (Walbaum), against Yersinia ruckeri challenge following oral administration of Bacillus subtilis and B. licheniformis (BioPlus2B) J. Fish Dis. 26, 495-498.

Rana, K.J., Siriwardena, S., Hasan, M.R., 2009. Impact of rising feed ingredient prices on aquafeeds and aquaculture production. FAO Fisheries and Aquaculture Technical Paper. No. 541. FAO, Rome (63 pp.).

Refstie, S., Baeverfjord, G., Seim, R.R., Elvebø, O., 2010. Effects of dietary yeast cell wall $\beta$-glucans and MOS on performance, gut health, and salmon lice resistance in Atlantic salmon (Salmo salar) fed sunflower and soybean meal. Aquaculture 305, 109-116.

Regost, C., Arzel, J., Kaushik, S.J., 1999. Partial or total replacement of fish meal by corn gluten meal in diet for turbot (Psetta maxima). Aquaculture 180, 99-117.

Riche, M., Brown, P.B., 1996. Availability of phosphorus from feedstuffs fed to rainbow trout, Oncorhynchus mykiss. Aquaculture 142, 269-282.

Ringø, E., Olsen, R.E., Gifstad, T.Ø., Dalmo, R.A., Amlund, H., Hemre, G.I., Bakke, A.M., 2010 Prebiotics in aquaculture: a review. Aquacult. Nutr. 16, 117-136.

Ringø, E., Olsen, R.E., Vecino, J.L.G., Wadsworth, S., Song, S.K., 2012. Use of immunostimulants and nucleotides in aquaculture: a review. J. Marine Sci. Res. Dev. 1, 104.

Salze, G., McLean, E., Battle, P.R., Schwarz, M.H., Craig, S.R., 2010. Use of soy protein concentrate and novel ingredients in the total elimination of fish meal and fish oil in diets for juvenile cobia, Rachycentron canadum. Aquaculture 298, 294-299.

Sanderson, I.R., He, Y., 1994. Nucleotide uptake and metabolism by intestinal epithelial cells. J. Nutr. 124, 131S-137S.

Santarém, M., Novoa, B., Figueras, A., 1997. Effects of $\beta$-glucans on the non-specific immune responses of turbot (Scophthalmus maximus L.). Fish Shellfish Immunol. 7, 429-437.

Schram, E., Verdegem, M.C.J., Widjaja, R.T.O.B.H., Kloet, C.J., Foss, A., Schelvis-Smit, R., Roth, B., Imsland, A.K., 2009. Impact of increased flow rate on specific growth rate of juvenile turbot (Scophthalmus maximus, Rafinesque 1810). Aquaculture 292, 46-52.

Selvaraj, V., Sampath, K., Sekar, V., 2005. Administration of yeast glucan enhances survival and some non-specific and specific immune parameters in carp (Cyprinus carpio) infected with Aeromonas hydrophila. Fish Shellfish Immunol. 19, 293-306.

Sheikhzadeh, N., Heidarieh, M., Karimi Pashaki, A., Nofouzi, K., Ahrab Farshbafi, M., Akbari, M., 2012. Hilyses ${ }^{\circledR}$, fermented Saccharomyces cerevisiae, enhances the growth performance and skin non-specific immune parameters in rainbow trout (Oncorhynchus mykiss). Fish Shellfish Immunol. 32, 1083-1087.

Staykov, Y., Spring, P., Denev, S., Sweetman, J., 2007. Effect of a mannan oligosaccharide on the growth performance and immune status of rainbow trout (Oncorhynchus mykiss). Aquacult. Int. 15, 153-161.

Storebakken, T., Shearer, K.D., Baeverfjord, G., Nielsen, B.G., Åsgård, T., Scott, T., De Laporte, A., 2000. Digestibility of macronutrients, energy and amino acids, absorption of elements and absence of intestinal enteritis in Atlantic salmon, Salmo salar, fed diets with wheat gluten. Aquaculture 184, 115-132.

Tacon, A.G.J., Metian, M., 2008. Global overview on the use of fish meal and fish oil in industrially compounded aquafeeds: trends and future prospects. Aquaculture 285, $146-158$.

Tahmasebi-Kohyani, A., Keyvanshokooh, S., Nematollahi, A., Mahmoudi, N., PashaZanoosi, H., 2012. Effects of dietary nucleotides supplementation on rainbow trout (Oncorhynchus mykiss) performance and acute stress response. Fish Physiol. Biochem. 38, 431-440. 
Tal, Y., Schreier, H.J., Sowers, K.R., Stubblefield, J.D., Place, A.R., Zohar, Y., 2009. Environmentally sustainable land-based marine aquaculture. Aquaculture 286, 28-35.

Torrecillas, S., Makol, A., Caballero, M.J., Montero, D., Dhanasiri, A.K.S., Sweetman, J., Izquierdo, M., 2012. Effects on mortality and stress response in European sea bass, Dicentrarchus labrax (L.), fed mannan oligosaccharides (MOS) after Vibrio anguillarum exposure. J. Fish Dis. 35, 591-602.

Valente, L.M.P., Linares, F., Villanueva, J.L.R., Silva, J.M.G., Espe, M., Escórcio, C., Pires, M.A. Saavedra, M.J., Borges, P., Medale, F., Alvárez-Blázquez, B., Peleteiro, J.B., 2011. Dietary protein source or energy levels have no major impact on growth performance nutrient utilisation or flesh fatty acids composition of market-sized Senegalese sole. Aquaculture 318, 128-137.

van Bussel, C.G.J., Schroeder, J.P., Wuertz, S., Schulz, C., 2012. The chronic effect of nitrate on production performance and health status of juvenile turbot (Psetta maxima). Aquaculture 326-329, 163-167.

Van Ham, E.H., Berntssen, M.H.G., Imsland, A.K. Parpoura, A.C., Wendelaar Bonga, S.E. Stefansson, S.O., 2003. The influence of temperature and ration on growth, feed conversion, body composition and nutrient retention of juvenile turbot (Scophthalmus maximus). Aquaculture 217, 547-558.

Watanabe, T., 2002. Strategies for further development of aquatic feeds. Fish. Sci. 68, 242-252.

Welker, T.L., Lim, C., Yildirim-Aksoy, M., Shelby, R., Klesius, P.H., 2007. Immune response and resistance to stress and Edwardsiella ictaluri challenge in channel catfish, Ictalurus punctatus, fed diets containing commercial whole-cell yeast or yeast subcomponents. J. World Aquacult. Soc. 38, 24-35.
Whittington, R., Lim, C., Klesius, P.H., 2005. Effect of dietary $\beta$-glucan levels on the growth response and efficacy of Streptococcus iniae vaccine in Nile tilapia, Oreochromis niloticus. Aquaculture 248, 217-225.

Yeh, S.-P., Chang, C.-A., Chang, C.-Y., Liu, C.-H., Cheng, W., 2008. Dietary sodium alginate administration affects fingerling growth and resistance to Streptococcus sp. and iridovirus, and juvenile non-specific immune responses of the orange-spotted grouper, Epinephelus coioides. Fish Shellfish Immunol. 25, 19-27.

Yoo, G, Lee, S, Kim, Y.C Okorie, O.E Park, GJ Han, Y.O Choi, S.-M, Kang, J.-C., Sun, M. Bai, S.C., 2007. Effects of dietary $\beta-1,3$ glucan and feed stimulants in juvenile olive flounder, Paralichthys olivaceus. J. World Aquacult. Soc. 38, 138-145.

Yun, B., Mai, K., Zhang, W., Xu, W., 2011. Effects of dietary cholesterol on growth performance, feed intake and cholesterol metabolism in juvenile turbot (Scophthalmus maximus L.) fed high plant protein diets. Aquaculture 319, 105-110.

Zeković, D.B., Kwiatkowski, S., Vrvić, M.M., Jakovljević, D., Moran, C.A., 2005. Natural and modified $(1 \rightarrow 3)-\beta-D-$ glucans in health promotion and disease alleviation. Crit. Rev. Biotechnol. 25, 205-230.

Zhou, Z., Liu, Y., He, S., Shi, P., Gao, X., Yao, B., Ringø, E., 2009. Effects of dietary potassium diformate (KDF) on growth performance, feed conversion and intestinal bacterial community of hybrid tilapia (Oreochromis niloticus + $\times 0$. aureus ${ }^{7}$ ). Aquaculture $291,89-94$ 